\title{
Effects of Aqueous Eucalyptus Extracts on Seed Germination and Seedling Growth of Phaseolus vulgaris L. and Zea mays L.
}

\author{
Wasihun Regu Gurmu \\ Department of Natural Resource Management, Hawassa Agricultural Research Center, \\ Hawassa, Ethiopia \\ Email: wasihunr@gmail.com
}

Received 21 August 2015; accepted 7 September 2015; published 11 September 2015

Copyright (C) 2015 by author and OALib.

This work is licensed under the Creative Commons Attribution International License (CC BY). http://creativecommons.org/licenses/by/4.0/

(c) (i) Open Access

\begin{abstract}
Allelopathic effects of Eucalyptus are widely reported and are considered the major factor limiting the cultivation of agricultural crops intercropped. However, reports of the allelopathic effects of Eucalyptus are mostly based on laboratory bioassay, not on field trials. The objective of the present study was to determine the effects of different leaves powder proportions of Eucalyptus species on agricultural crops as well as change in soil reaction. This research was undertaken in a pot experiment that haricot bean and maize grown in the nursery of Hawassa University College of Agriculture campus laid in a completely randomized design. Collected leaves of Eucalyptus camaldulensis and Eucalyptus grandis were prepared powdered by air drying and grinding. Results suggested that leaves powder of each tree species induced significant inhibitory effect on germination and seedling growth of each crops compared to the control treatments. Application of low-dose leaves powder of either tree species had low effect on both crops. Eucalyptus grandis has more inhibitory effect on both crops, and the negative effect of allelochemicals is more pronounced on haricot bean. This indicates that maize and haricot bean should not be planted very close to Eucalyptus trees and crops seed rate should be increased to get the maximum germination.
\end{abstract}

\section{Keywords}

Allelopathy, Eucalyptus camaldulensis, Eucalyptus grandis, Germination, Phaseolus vulgaris, Seedling Growth, Zea mays

Subject Areas: Agricultural Science 


\section{Introduction}

Forest plantations in Ethiopia are mainly mono-culture of exotic species. Nevertheless, they are predominantly mono-culture of Eucalyptus species that are estimated to cover about 93\% of the total plantation area in the country [1]. Nowadays, many people in Ethiopia are dependent on Eucalyptus for fuel wood, construction wood, income generation and it is highly favored for planting near and outside the croplands [2].

In the traditional agroforestry system of southern Ethiopia, people are growing several trees including Eucalyptus species in or around the agricultural fields as a boundary or woodlot [3]. Among Agricultural crops Haricot bean and Maize are one of the top priority crops and the basic staple food crops of the majority of the population in the region.

While Eucalyptus has many benefits, of all widely used plantation species they have attracted by far the most criticism [1]. Some of the critics associated with it are: the species do not provide organic matter and depletes soil nutrients needed by agricultural crops; it depletes water resources and competes with agricultural crops; it suppresses ground vegetation resulting unsuitability to soil erosion control and it is believed to have allelopathic effect [4].

To discourage or promote the planting of Eucalyptus and to use them for agroforestry purposes, sufficient scientific evidences on the ecological impact, on undergrowth vegetation, soil fertility, and the quality of the product should be further investigated [5]. The primary objective of this study was to elucidate the allelopathic potential of different leaves powder proportions of Eucalyptus camaldulensis and Eucalyptus grandis on haricot bean and maize crop seedlings.

\section{Materials and Methods}

The study was conducted in the nursery site of Hawassa University College of Agriculture from December to March 2011. Eucalyptus species were considered from the plantation at Wondo-Genet College of Forestry and Natural Resources.

Randomly collecting fresh leaves of 2 to 3-year-old Eucalyptus grandis and Eucalyptus camaldulensis from the top, middle and bottom canopy and they were dried in an open air under shade for two days; the leaves were then put in oven with a temperature of $50^{\circ} \mathrm{C}$ for 48 hours [6]. All the leaves samples were prepared powder to fine particles using electric grinder and stored in plastic bags at room temperature until its application into pots. Seeds of maize (ACV6 variety) and haricot bean (Melkasa1 variety) were obtained from Hawassa College of Agriculture and used in the study as recipient crops.

The experiment was laid down in a Complete Randomized Design (CRD) which has uniform plots or growing medias. Pots were prepared and arranged in rows for both crops independently and fairly leveled by adding local top soil collected from 0 - $30 \mathrm{~cm}$ depth.

Equal amount of water was added into all the plastic pots and kept for one week in the net house provided with plastic sheets to develop any possible microbial activity prior to sowing. The seeds of both crops were floated in water to eliminate the empty ones, and then, 4 seeds of haricot bean and four grains of maize were planted in each of the treated plastic pots having $42 \mathrm{~cm}$ depth, $30 \mathrm{~cm}$ top and $20 \mathrm{~cm}$ bottom diameters provided with drainage holes. The pots were watered every two days on the average with normal tap water. After emergence, seedlings were thinned to two plants per pot. The experiment continued over a period of 21 days in which the final measurements were recorded.

Leaves powder weighing a total of $4.08 \mathrm{~kg}$ of each of the two Eucalyptus species were prepared and mixed with pot soil uniformly in the following treatment proportions as: (Control, $10 \mathrm{~g}$ powder/pot, $100 \mathrm{~g}$ powder/pot, $150 \mathrm{~g}$ powder/pot and $200 \mathrm{~g}$ powder/pot) replicated four times for each crop consisting a total of 96 pots/experimental units.

The germination was recorded and determined using Germination $(\%)=($ No of germinated seeds/Total No of seeds sown) $\times 100[7]$.

Shoot length measurements were taken from the stem joint to the tip of the terminal leaf. Root length measurements were taken from the root joint to the tip of the tap/main root. Collar diameters of both crops were determined using a caliper. Shoot and root fresh weight, Shoot and root dry weights (g) were measured using scientific electrical balance. Shoot and root dry weights (g) were measured after dried in oven at $65^{\circ} \mathrm{C}$ for 24 hours. The $\mathrm{pH}$ for each treatment was determined by using sample of $5 \mathrm{~g}$ in $25 \mathrm{ml}$ of distilled water with the help of pH meter [8]-[10]. 
The analysis of variance was conducted for germination, crop seedling growth parameters and soil $\mathrm{pH}$ by the general linear model procedure and means were compared for all significant parameters using Least Significant Difference test at 0.05 probability level using SAS software version 9 [11]. Percent inhibition or stimulation of each treatments was calculated as percent inhibition or stimulation $=100-($ treatment value/control value $) \times 100$ [4].

\section{Results}

\subsection{Effect of Eucalyptus grandis on Haricot Bean and Maize}

The results of seed germination showed that majority of treatment levels of Eucalyptus grandis significantly ( $p \leq$ 0.05) reduced maize and haricot bean seed germination (Table 1 and Table 2) except treatment levels of 10 and $50 \mathrm{~g} /$ pot in maize the rest showed significant effect compared to the control treatment, and a $200 \mathrm{~g} / \mathrm{pot}$ showed statistical similar with $150 \mathrm{~g} /$ pot. For haricot bean all treatments are statistically significant compared to the control and there is no significant different between all treatment levels.

Table 1. Response to allelopathic effect of Eucalyptus grandis on germination and growth of haricot bean seedlings.

\begin{tabular}{|c|c|c|c|c|c|c|c|c|c|}
\hline Treatments & $\begin{array}{c}\text { Germination } \\
(\%)\end{array}$ & $\begin{array}{l}\text { Shoot } \\
\text { length } \\
(\mathrm{cm})\end{array}$ & $\begin{array}{l}\text { Root } \\
\text { length } \\
(\mathrm{cm})\end{array}$ & $\begin{array}{l}\text { Collar } \\
\text { diameter } \\
(\mathrm{cm})\end{array}$ & $\begin{array}{l}\text { Shoot fresh } \\
\text { weight (g) }\end{array}$ & $\begin{array}{l}\text { Root fresh } \\
\text { weight (g) }\end{array}$ & $\begin{array}{l}\text { Shoot dry } \\
\text { weight (g) }\end{array}$ & $\begin{array}{c}\text { Root dry } \\
\text { weight (g) }\end{array}$ & $\begin{array}{l}\text { Soil } \\
\text { reaction } \\
(\mathrm{pH})\end{array}$ \\
\hline Control & $91.67 a$ & $16.10 \mathrm{a}$ & $17.00 \mathrm{a}$ & $0.41 \mathrm{a}$ & $3.61 \mathrm{a}$ & $0.19 a$ & $1.00 \mathrm{a}$ & $0.13 a$ & $8.08 a$ \\
\hline $10 \mathrm{~g} / \mathrm{pot}$ & $\begin{array}{l}41.67 \mathrm{~b} \\
(-54.5)\end{array}$ & $\begin{array}{l}9.98 b \\
(-38)\end{array}$ & $\begin{array}{l}10.50 \mathrm{~b} \\
(-38.2)\end{array}$ & $\begin{array}{c}0.35 a \\
(-14.5)\end{array}$ & $\begin{array}{c}1.25 b \\
(-65.4)\end{array}$ & $\begin{array}{c}0.10 \mathrm{~b} \\
(-48.1)\end{array}$ & $\begin{array}{c}0.46 \mathrm{~b} \\
(-54.5)\end{array}$ & $\begin{array}{c}0.07 \mathrm{~b} \\
(-48.8)\end{array}$ & $\begin{array}{c}7.75 b \\
(-4)\end{array}$ \\
\hline $50 \mathrm{~g} /$ pot & $\begin{array}{l}33.33 b \\
(-63.6)\end{array}$ & $\begin{array}{l}8.50 \mathrm{~b} \\
(-47.2)\end{array}$ & $\begin{array}{l}9.25 b c \\
(-45.6)\end{array}$ & $\begin{array}{c}0.34 \mathrm{a} \\
(-18.8)\end{array}$ & $\begin{array}{c}0.96 \mathrm{~b} \\
(-73.5)\end{array}$ & $\begin{array}{c}0.07 b c \\
(-66.2)\end{array}$ & $\begin{array}{c}0.29 b c \\
(-71.5)\end{array}$ & $\begin{array}{l}0.05 b c \\
(-65)\end{array}$ & $\begin{array}{l}\text { 7.63bc } \\
(-5.6)\end{array}$ \\
\hline 100 g/pot & $\begin{array}{l}33.33 b \\
(-63.6)\end{array}$ & $\begin{array}{l}6.38 b c \\
(-60.4)\end{array}$ & $\begin{array}{l}6.88 \mathrm{bc} \\
(-59.6)\end{array}$ & $\begin{array}{c}0.20 \mathrm{~b} \\
(-51.5)\end{array}$ & $\begin{array}{c}0.38 b \\
(-89.5)\end{array}$ & $\begin{array}{c}0.03 c d \\
(-82.3)\end{array}$ & $\begin{array}{c}0.23 \mathrm{bc} \\
(-77.3)\end{array}$ & $\begin{array}{c}0.01 \mathrm{c} \\
(-91.3)\end{array}$ & $\begin{array}{l}7.53 \mathrm{bc} \\
(-6.8)\end{array}$ \\
\hline 150 g/pot & $\begin{array}{l}33.33 b \\
(-63.6)\end{array}$ & $\begin{array}{l}4.25 \mathrm{~cd} \\
(-73.6)\end{array}$ & $\begin{array}{l}5.88 \mathrm{bc} \\
(-65.4)\end{array}$ & $\begin{array}{c}0.13 \mathrm{bc} \\
(-68.8)\end{array}$ & $\begin{array}{c}0.19 \mathrm{~b} \\
(-94.7)\end{array}$ & $\begin{array}{l}0.02 \mathrm{~cd} \\
(-88.8)\end{array}$ & $\begin{array}{l}0.16 \mathrm{bc} \\
(-84.5)\end{array}$ & $\begin{array}{c}0.01 \mathrm{c} \\
(-94.4)\end{array}$ & $\begin{array}{l}7.45 \mathrm{bc} \\
(-7.7)\end{array}$ \\
\hline 200 g/pot & $\begin{array}{l}33.33 \mathrm{~b} \\
(-63.6)\end{array}$ & $\begin{array}{c}2.15 d \\
(-86.6)\end{array}$ & $\begin{array}{c}3.75 c \\
(-77.9)\end{array}$ & $\begin{array}{c}0.06 \mathrm{c} \\
(-85.2)\end{array}$ & $\begin{array}{l}0.11 \mathrm{~b} \\
(-97)\end{array}$ & $\begin{array}{l}0.012 \mathrm{~d} \\
(-95.3)\end{array}$ & $\begin{array}{c}0.09 \mathrm{c} \\
(-90.1)\end{array}$ & $\begin{array}{l}0.01 \mathrm{c} \\
(-95)\end{array}$ & $\begin{array}{l}7.38 \mathrm{c} \\
(-8.7)\end{array}$ \\
\hline LSD @ $p \leq 0.05$ & 14.29 & 4.17 & 6.43 & 0.12 & 1.82 & 0.05 & 0.33 & 0.05 & 0.30 \\
\hline
\end{tabular}

${ }^{*}$ Means in the same column followed by the same letter are not significantly different according to LSD at probability level of 0.05 . Value in the parenthesis indicates \% inhibitory (-) effects in comparison to control.

Table 2. Response to allelopathic effect of Eucalyptus grandis on germination and growth of maize seedlings.

\begin{tabular}{|c|c|c|c|c|c|c|c|c|c|}
\hline Treatments & $\begin{array}{c}\text { Germination } \\
\text { (\%) }\end{array}$ & $\begin{array}{l}\text { Shoot } \\
\text { length } \\
(\mathrm{cm})\end{array}$ & $\begin{array}{l}\text { Root } \\
\text { length } \\
(\mathrm{cm})\end{array}$ & $\begin{array}{l}\text { Collar } \\
\text { diameter } \\
\text { (cm) }\end{array}$ & $\begin{array}{l}\text { Shoot fresh } \\
\text { weight } \\
\text { (g) }\end{array}$ & $\begin{array}{l}\text { Root fresh } \\
\text { weight } \\
\text { (g) }\end{array}$ & $\begin{array}{l}\text { Shoot dry } \\
\text { weight } \\
\text { (g) }\end{array}$ & $\begin{array}{l}\text { Root dry } \\
\text { weight } \\
\text { (g) }\end{array}$ & $\begin{array}{l}\text { Soil } \\
\text { reaction } \\
(\mathrm{pH})\end{array}$ \\
\hline Control & $100 \mathrm{a}$ & 26.13a & $46.25 a$ & $0.91 \mathrm{a}$ & $10.9 \mathrm{a}$ & $2.45 a$ & $2.55 a$ & 1.88a & 8.03a \\
\hline $10 \mathrm{~g} / \mathrm{pot}$ & $100 \mathrm{a}$ & $\begin{array}{l}20.25 b \\
(-22.5)\end{array}$ & $\begin{array}{l}38.75 a \\
(-16.2)\end{array}$ & $\begin{array}{c}0.75 a \\
(-17.8)\end{array}$ & $\begin{array}{l}7.34 a b \\
(-32.8)\end{array}$ & $\begin{array}{l}1.09 b \\
(-55.3)\end{array}$ & $\begin{array}{l}1.55 b \\
(-39.2)\end{array}$ & $\begin{array}{c}0.72 b \\
(-61.5)\end{array}$ & $\begin{array}{l}7.85 \mathrm{ab} \\
(-2.2)\end{array}$ \\
\hline $50 \mathrm{~g} /$ pot & $\begin{array}{l}91.67 a \\
(-8.3)\end{array}$ & $\begin{array}{l}15.88 \mathrm{~b} \\
(-39.2)\end{array}$ & $\begin{array}{l}25.50 \mathrm{~b} \\
(-44.9)\end{array}$ & $\begin{array}{c}0.53 b \\
(-41.9)\end{array}$ & $\begin{array}{l}4.83 \mathrm{bc} \\
(-55.8)\end{array}$ & $\begin{array}{l}0.68 \mathrm{bc} \\
(-72.2)\end{array}$ & $\begin{array}{c}0.88 c \\
(-65.7)\end{array}$ & $\begin{array}{c}0.38 c \\
(-79.6)\end{array}$ & $\begin{array}{l}7.80 \mathrm{ab} \\
(-2.8)\end{array}$ \\
\hline $100 \mathrm{~g} / \mathrm{pot}$ & $\begin{array}{l}66.67 b \\
(-33.3)\end{array}$ & $\begin{array}{l}10.35 c \\
(-60.4)\end{array}$ & $\begin{array}{l}16.88 b c \\
(-63.5)\end{array}$ & $\begin{array}{c}0.42 \mathrm{bc} \\
(-54.5)\end{array}$ & $\begin{array}{c}1.42 \mathrm{c} \\
(-87.1)\end{array}$ & $\begin{array}{l}0.17 c d \\
(-93.1)\end{array}$ & $\begin{array}{c}0.18 d \\
(-93.1)\end{array}$ & $\begin{array}{c}0.13 c d \\
(-93.2)\end{array}$ & $\begin{array}{l}7.63 \mathrm{~b} \\
(-4.9)\end{array}$ \\
\hline $150 \mathrm{~g} / \mathrm{pot}$ & $\begin{array}{c}50.00 \mathrm{bc} \\
(-50)\end{array}$ & $\begin{array}{l}6.75 \mathrm{~cd} \\
(-74.2)\end{array}$ & $\begin{array}{l}10.38 \mathrm{c} \\
(-77.6)\end{array}$ & $\begin{array}{l}0.33 b c \\
(-64.1)\end{array}$ & $\begin{array}{c}0.71 \mathrm{c} \\
(-93.5)\end{array}$ & $\begin{array}{c}0.13 \mathrm{~d} \\
(-94.7)\end{array}$ & $\begin{array}{c}0.11 d \\
(-95.7)\end{array}$ & $\begin{array}{c}0.06 \mathrm{~d} \\
(-96.9)\end{array}$ & $\begin{array}{l}7.50 \mathrm{~b} \\
(-6.5)\end{array}$ \\
\hline $200 \mathrm{~g} / \mathrm{pot}$ & $\begin{array}{l}33.33 c \\
(-66.7)\end{array}$ & $\begin{array}{c}5.20 \mathrm{~d} \\
(-80.1)\end{array}$ & $\begin{array}{l}12.38 \mathrm{c} \\
(-73.2)\end{array}$ & $\begin{array}{c}0.21 \mathrm{c} \\
(-76.9)\end{array}$ & $\begin{array}{c}0.52 \mathrm{c} \\
(-95.2)\end{array}$ & $\begin{array}{c}0.07 d \\
(-97.1)\end{array}$ & $\begin{array}{c}0.04 d \\
(-98.3)\end{array}$ & $\begin{array}{c}0.04 \mathrm{~d} \\
(-97.9)\end{array}$ & $\begin{array}{c}7.10 \mathrm{c} \\
(-11.5)\end{array}$ \\
\hline LSD @ $p \leq 0.05$ & 22.60 & 5.08 & 12.64 & 0.22 & 4.38 & 0.51 & 0.66 & 0.27 & 0.39 \\
\hline
\end{tabular}

${ }^{*}$ Means in the same column followed by the same letter are not significantly different according to LSD at probability level of 0.05 . Value in the parenthesis indicates \% inhibitory ( - ) effects in comparison to control. 
The results of shoot length showed that all treatment levels of Eucalyptus grandis significantly $(p \leq 0.05)$ reduced both maize and haricot bean shoot length as compared to the control treatment (Table 1 and Table 2). For haricot bean all treatments are statistically significant compared to the control and there is no significant different between 10, 50 and $100 \mathrm{~g} /$ pot treatment levels. A $200 \mathrm{~g} /$ pot and $150 \mathrm{~g} /$ pot showed statistically similar and significantly different from the rest treatments. For maize all treatments are statistically significant compared to the control and there is no significant different between 10 and $50 \mathrm{~g} /$ pot treatment levels. The smallest mean shoot length was observed in the $200 \mathrm{~g} /$ pot treated pots for both crops.

The results of crops root length showed that all treatment levels of Eucalyptus grandis significantly $(p \leq 0.05)$ reduced both maize and haricot bean root length except for the $10 \mathrm{~g} /$ pot treatment in maize as compared to the control treatment (Table 1 and Table 2). The smallest mean root lengths were observed in the $200 \mathrm{~g} / \mathrm{pot}$ and 150 $\mathrm{g} /$ pot treated pots for haricot bean and maize respectively.

The results on collar diameter showed that majority of treatment levels of Eucalyptus grandis significantly ( $p \leq$ 0.05 ) reduced both maize and haricot bean collar diameter except for the 10 , and $50 \mathrm{~g} /$ pot levels compared to the control treatment (Table 1 and Table 2). The smallest mean collar diameter was observed in the $200 \mathrm{~g} / \mathrm{pot}$ treated pots for both crops.

The results showed that all treatment levels of Eucalyptus grandis significantly $(p \leq 0.05)$ reduced both maize and haricot bean shoot, root fresh and shoot, root dry weight except for the $10 \mathrm{~g} / \mathrm{pot}$ in maize shoot fresh weight as compared to the control treatment (Table 1 and Table 2). The smallest mean shoot, root fresh and shoot, root dry weight was observed in the $200 \mathrm{~g} / \mathrm{pot}$ treated pots for both crops. The results of soil $\mathrm{pH}$ showed that all treatment levels of Eucalyptus grandis significantly $(p \leq 0.05)$ reduced soil $\mathrm{pH}$ in maize and haricot bean pot except for the 10, and $50 \mathrm{~g} /$ pot in maize pot as compared to the control treatment (Table 1 and Table 2). The smallest mean soil pH was observed in a $200 \mathrm{~g} /$ pot treated pots for both crops.

\subsection{Effect of Eucalyptus camaldulensis on Haricot Bean and Maize}

The results of seed germination showed that all treatment levels of Eucalyptus camaldulensis significantly ( $p \leq$ 0.05 ) reduced maize and haricot bean seed germination except for the $10 \mathrm{~g} / \mathrm{pot}$ in haricot bean as compared to the control treatment (Table 3 and Table 4). The smallest mean seed Germination and statistically similar with $150 \mathrm{~g} /$ pot was observed in the $200 \mathrm{~g} /$ pot treated pots for maize. The smallest mean seed germination was observed in the 150 and $200 \mathrm{~g} /$ pot treated pots for haricot bean and in the $200 \mathrm{~g} /$ pot treated pots for maize.

The result of shoot length showed that all treatment levels of Eucalyptus camaldulensis significantly $(p \leq 0.05)$ reduced both maize and haricot bean shoot length except for the $10 \mathrm{~g} /$ pot in haricot bean as compared to the control treatment (Table 3 and Table 4). Even if there is a statistical similarity between 100, 150 and $200 \mathrm{~g} / \mathrm{pot}$ treatments for haricot bean, and between 150 and 200 g/pot treatments for maize the smallest mean shoot length was observed in the $200 \mathrm{~g} /$ pot treated pots for both crops.

Table 3. Response to allelopathic effect of Eucalyptus camaldulensis on germination and growth of haricot bean seedlings.

\begin{tabular}{|c|c|c|c|c|c|c|c|c|c|}
\hline Treatments & $\begin{array}{c}\text { Germination } \\
(\%)\end{array}$ & $\begin{array}{l}\text { Shoot } \\
\text { length } \\
(\mathrm{cm})\end{array}$ & $\begin{array}{l}\text { Root } \\
\text { length } \\
(\mathrm{cm})\end{array}$ & $\begin{array}{l}\text { Collar } \\
\text { diameter } \\
(\mathrm{cm})\end{array}$ & $\begin{array}{l}\text { Shoot fresh } \\
\text { weight (g) }\end{array}$ & $\begin{array}{l}\text { Root fresh } \\
\text { weight (g) }\end{array}$ & $\begin{array}{l}\text { Shoot dry } \\
\text { weight (g) }\end{array}$ & $\begin{array}{c}\text { Root dry } \\
\text { weight (g) }\end{array}$ & $\begin{array}{c}\text { Soil } \\
\text { reaction } \\
(\mathrm{pH})\end{array}$ \\
\hline Control & $100 a$ & $16.50 \mathrm{a}$ & $22 \mathrm{a}$ & $0.43 a$ & 3.69a & $0.27 a$ & $1.08 \mathrm{a}$ & $0.17 \mathrm{a}$ & $8.08 a$ \\
\hline $10 \mathrm{~g} / \mathrm{pot}$ & $\begin{array}{c}91.67 \mathrm{ab} \\
(-8.3)\end{array}$ & $\begin{array}{c}14.68 a b \\
(-11.1)\end{array}$ & $\begin{array}{l}14.38 b \\
(-34.6)\end{array}$ & $\begin{array}{l}0.38 a b \\
(-10.6)\end{array}$ & $\begin{array}{l}2.08 \mathrm{ab} \\
(-44.9)\end{array}$ & $\begin{array}{c}0.13 b \\
(-53.3)\end{array}$ & $\begin{array}{l}0.75 a b \\
(-30.2)\end{array}$ & $\begin{array}{c}0.08 b \\
(-55.1)\end{array}$ & $\begin{array}{l}\text { 7.93ab } \\
(-1.9)\end{array}$ \\
\hline $50 \mathrm{~g} / \mathrm{pot}$ & $\begin{array}{c}75.00 \mathrm{~b} \\
(-25)\end{array}$ & $\begin{array}{l}12.43 b c \\
(-24.7)\end{array}$ & $\begin{array}{l}9.43 \mathrm{bc} \\
(-57.2)\end{array}$ & $\begin{array}{l}0.32 \mathrm{bc} \\
(-24.1)\end{array}$ & $\begin{array}{c}1.45 b \\
(-60.9)\end{array}$ & $\begin{array}{l}0.11 \mathrm{bc} \\
(-59.9)\end{array}$ & $\begin{array}{l}0.47 \mathrm{bc} \\
(-56.5)\end{array}$ & $\begin{array}{c}0.04 b \\
(-74.9)\end{array}$ & $\begin{array}{l}7.85 b \\
(-2.8)\end{array}$ \\
\hline $100 \mathrm{~g} / \mathrm{pot}$ & $\begin{array}{l}41.67 c \\
(-58.3)\end{array}$ & $\begin{array}{l}10.48 c d \\
(-36.5)\end{array}$ & $\begin{array}{l}7.98 \mathrm{bc} \\
(-63.8)\end{array}$ & $\begin{array}{l}0.28 \mathrm{~cd} \\
(-35.3)\end{array}$ & $\begin{array}{c}1.16 b \\
(-68.7)\end{array}$ & $\begin{array}{l}0.08 \mathrm{bc} \\
(-71.9)\end{array}$ & $\begin{array}{c}0.37 b c \\
(-66)\end{array}$ & $\begin{array}{c}0.03 b \\
(-85.5)\end{array}$ & $\begin{array}{c}7.75 b c \\
(-4)\end{array}$ \\
\hline $150 \mathrm{~g} / \mathrm{pot}$ & $\begin{array}{l}33.33 c \\
(-66.7)\end{array}$ & $\begin{array}{l}\text { 10.13cd } \\
(-38.6)\end{array}$ & $\begin{array}{l}7.38 b c \\
(-66.5)\end{array}$ & $\begin{array}{l}0.21 d \\
(-50)\end{array}$ & $\begin{array}{c}0.86 b \\
(-76.7)\end{array}$ & $\begin{array}{l}0.04 \mathrm{bc} \\
(-84.9)\end{array}$ & $\begin{array}{c}0.28 \mathrm{c} \\
(-73.7)\end{array}$ & $\begin{array}{c}0.02 b \\
(-88.1)\end{array}$ & $\begin{array}{l}7.63 \mathrm{~cd} \\
(-5.6)\end{array}$ \\
\hline $200 \mathrm{~g} / \mathrm{pot}$ & $\begin{array}{l}33.33 c \\
(-66.7)\end{array}$ & $\begin{array}{c}7.13 d \\
(-56.8)\end{array}$ & $\begin{array}{c}5.13 c \\
(-76.7)\end{array}$ & $\begin{array}{c}0.18 d \\
(-57.1)\end{array}$ & $\begin{array}{c}0.55 b \\
(-85.1)\end{array}$ & $\begin{array}{c}0.02 \mathrm{c} \\
(-93.4)\end{array}$ & $\begin{array}{c}0.16 c \\
(-85.3)\end{array}$ & $\begin{array}{c}0.01 b \\
(-94.2)\end{array}$ & $\begin{array}{l}7.45 d \\
(-7.7)\end{array}$ \\
\hline LSD@p $\leq 0.05$ & 24.06 & 4.06 & 7.41 & 0.09 & 1.69 & 0.09 & 0.42 & 0.07 & 0.19 \\
\hline
\end{tabular}

*Means in the same column followed by the same letter are not significantly different according to LSD at probability level of 0.05. Value in the parenthesis indicates \% inhibitory (-) effects in comparison to control. 
Table 4. Response to allelopathic effect of Eucalyptus camaldulensis on germination and growth of maize seedlings.

\begin{tabular}{|c|c|c|c|c|c|c|c|c|c|}
\hline Treatments & $\begin{array}{c}\text { Germination } \\
\text { (\%) }\end{array}$ & $\begin{array}{l}\text { Shoot } \\
\text { length } \\
(\mathrm{cm})\end{array}$ & $\begin{array}{l}\text { Root } \\
\text { length } \\
(\mathrm{cm})\end{array}$ & $\begin{array}{l}\text { Collar } \\
\text { diameter } \\
\text { (cm) }\end{array}$ & $\begin{array}{l}\text { Shoot fresh } \\
\text { weight (g) }\end{array}$ & $\begin{array}{l}\text { Root fresh } \\
\text { weight (g) }\end{array}$ & $\begin{array}{l}\text { Shoot dry } \\
\text { weight (g) }\end{array}$ & $\begin{array}{c}\text { Root dry } \\
\text { weight (g) }\end{array}$ & $\begin{array}{l}\text { Soil } \\
\text { reaction } \\
(\mathrm{pH})\end{array}$ \\
\hline Control & $91.67 a$ & $30.25 a$ & $50.75 a$ & $1.04 \mathrm{a}$ & $18.62 a$ & $2.45 a$ & $3.30 \mathrm{a}$ & $1.88 \mathrm{a}$ & $7.85 \mathrm{a}$ \\
\hline $10 \mathrm{~g} / \mathrm{pot}$ & $\begin{array}{l}91.67 \mathrm{a} \\
(-8.3)\end{array}$ & $\begin{array}{l}25.25 b \\
(-16.5)\end{array}$ & $\begin{array}{l}40.38 b \\
(-20.4)\end{array}$ & $\begin{array}{c}0.91 \mathrm{a} \\
(-13.2)\end{array}$ & $\begin{array}{l}11.49 b \\
(-38.3)\end{array}$ & $\begin{array}{l}1.88 b \\
(-23.1)\end{array}$ & $\begin{array}{l}2.38 \mathrm{~b} \\
(-28)\end{array}$ & $\begin{array}{l}0.98 b \\
(-48)\end{array}$ & $\begin{array}{l}7.70 \mathrm{a} \\
(-1.9)\end{array}$ \\
\hline $50 \mathrm{~g} / \mathrm{pot}$ & $\begin{array}{l}83.33 a \\
(-9.1)\end{array}$ & $\begin{array}{l}20.63 c \\
(-31.8)\end{array}$ & $\begin{array}{l}40.50 \mathrm{~b} \\
(-20.2)\end{array}$ & $\begin{array}{c}0.75 b \\
(-28.3)\end{array}$ & $\begin{array}{l}7.89 \mathrm{bc} \\
(-57.6)\end{array}$ & $\begin{array}{c}1.02 \mathrm{c} \\
(-58.4)\end{array}$ & $\begin{array}{l}1.63 b c \\
(-50.8)\end{array}$ & $\begin{array}{c}0.65 c \\
(-65.3)\end{array}$ & $\begin{array}{l}7.50 \mathrm{ab} \\
(-4.5)\end{array}$ \\
\hline $100 \mathrm{~g} / \mathrm{pot}$ & $\begin{array}{l}83.33 a \\
(-9.1)\end{array}$ & $\begin{array}{l}15.63 d \\
(-48.3)\end{array}$ & $\begin{array}{l}29.25 c \\
(-42.3)\end{array}$ & $\begin{array}{c}0.64 b \\
(-38.8)\end{array}$ & $\begin{array}{l}4.62 \mathrm{~cd} \\
(-75.2)\end{array}$ & $\begin{array}{l}0.69 \mathrm{~cd} \\
(-71.7)\end{array}$ & $\begin{array}{l}0.98 \mathrm{~cd} \\
(-70.5)\end{array}$ & $\begin{array}{c}0.45 \mathrm{~cd} \\
(-76)\end{array}$ & $\begin{array}{l}7.45 a b \\
(-5.1)\end{array}$ \\
\hline $150 \mathrm{~g} / \mathrm{pot}$ & $\begin{array}{l}66.67 a b \\
(-27.3)\end{array}$ & $\begin{array}{l}9.98 \mathrm{e} \\
(-67)\end{array}$ & $\begin{array}{l}16.33 d \\
(-67.8)\end{array}$ & $\begin{array}{c}0.46 c \\
(-56.4)\end{array}$ & $\begin{array}{c}1.45 d \\
(-92.2)\end{array}$ & $\begin{array}{c}0.25 \mathrm{e} \\
(-89.8)\end{array}$ & $\begin{array}{c}0.33 d \\
(-90.2)\end{array}$ & $\begin{array}{l}0.22 \text { de } \\
(-88.3)\end{array}$ & $\begin{array}{l}7.40 \mathrm{ab} \\
(-5.7)\end{array}$ \\
\hline $200 \mathrm{~g} /$ pot & $\begin{array}{l}41.67 \mathrm{~b} \\
(-54.5)\end{array}$ & $\begin{array}{l}7.25 \mathrm{e} \\
(-76)\end{array}$ & $\begin{array}{c}12 \mathrm{~d} \\
(-76.4)\end{array}$ & $\begin{array}{c}0.35 c \\
(-66.7)\end{array}$ & $\begin{array}{c}0.78 d \\
(-95.8)\end{array}$ & $\begin{array}{c}0.22 \mathrm{de} \\
(-91.2)\end{array}$ & $\begin{array}{c}0.13 d \\
(-96.2)\end{array}$ & $\begin{array}{c}0.07 \mathrm{e} \\
(-96.1)\end{array}$ & $\begin{array}{l}7.23 \mathrm{~b} \\
(-7.9)\end{array}$ \\
\hline LSD @p $\leq 0.05$ & 29.18 & 4.39 & 8.08 & 0.14 & 4.57 & 0.46 & 0.86 & 0.29 & 0.45 \\
\hline
\end{tabular}

*Means in the same column followed by the same letter are not significantly different according to LSD at probability level of 0.05 . Value in the parenthesis indicates \% inhibitory (-) effects in comparison to control.

The results of root length showed that all treatment levels of Eucalyptus camaldulensis significantly ( $p \leq 0.05)$ reduced both maize and haricot bean root length as compared to the control treatment (Table 3 and Table 4). The smallest mean root length was observed in the $200 \mathrm{~g} /$ pot treated pots for both crops.

The results on collar diameter showed that the majority of treatment levels of Eucalyptus camaldulensis significantly ( $p \leq 0.05$ ) reduced both maize and haricot bean collar diameter except for $10 \mathrm{~g} / \mathrm{pot}$ in both crops as compared to the control treatment (Table 3 and Table 4). The smallest mean collar diameter was observed in the $200 \mathrm{~g} /$ pot treated pots for both crops, even though it has a statistical similarity with 100 and $150 \mathrm{~g} /$ pot in haricot bean and with $150 \mathrm{~g} / \mathrm{pot}$ in maize.

The results showed that all treatment levels of Eucalyptus camaldulensis significantly $(p \leq 0.05)$ reduced both maize and haricot bean shoot, root fresh and shoot, root dry weight except for the $10 \mathrm{~g} /$ pot in haricot bean shoot fresh weight and shoot dry weight as compared to the control treatment (Table 3 and Table 4). The smallest mean shoot, root fresh and shoot, root dry weight was observed in the $200 \mathrm{~g} /$ pot treated pots for both crops, even though it has statistical similarity with all treatments in haricot bean shoot fresh and root dry weight and except with a $10 \mathrm{~g} /$ pot of root fresh and shoot dry weight.

The results of soil $\mathrm{pH}$ showed that except treatment $10 \mathrm{~g} / \mathrm{pot}$, the rest all treatment levels of Eucalyptus camaldulensis significantly $(p \leq 0.05)$ reduced soil $\mathrm{pH}$ in haricot bean and maize pots as compared to the control treatments (Table 3 and Table 4). More over all treatments were statistical similar except for treatment level of $200 \mathrm{~g} / \mathrm{pot}$ where significantly the smallest soil pH was observed for both crops.

\section{Discussion}

The present study revealed that no treatments of both Eucalyptus species had stimulating effect on all measured parameters of either test crops except no noticeable effect in the treatment of 10 g/pot of Eucalyptus grandis on maize germination as compared to control. Probable reasons for this could be the elevated amount of allelochemicals and inhibitory effect present in each Eucalyptus species leaf powder that affected the essential growth processes. From the mean results, the effect increased with the increase of leaf powder application. Similar studies elsewhere have found that inhibitory effect of Eucalyptus camaldulensis depended on concentration of extract and litter-fall with higher concentration of the materials, having higher effects and vice versa [12]. These results are also in agreement with those reported by Lisanework and Michelson [13] who noted a decrease in germination of maize due to applied Eucalyptus globules, Eucalyptus camaldulensis and Eucalyptus saligna extract. The results validate the findings of Ebrahim et al., Khan et al. [14], [15] who reported that leaf extract of Eucalyptus camaldulensis and Eucalyptus microthecia delayed and inhibited germination of maize. Thakur and Bhardwaj [16] also reported that leachates from E. globulus leave significantly reduce maize germination. Rao and Reddy [17] reported inhibition of germination and other growth parameters in horse gram, green gram, 
cowpeas and beans due to the leaf extracts of Eucalyptus camaldulensis. Shivanna et al. [18] also reported the allelopathic effect of Eucalyptus camaldulensis on rag (Eleusinecoracana), Cowpeas (Vignaungnicalanta) and Sesmum (Sesmum indicum).

The highest reduction in the mean shoot length of haricot bean and maize was observed in the $200 \mathrm{~g} / \mathrm{pot}$ of Eucalyptus grandis treated pots with values of $86.6 \%$ and $80.1 \%$. Similarly, the highest reductions in the mean shoot length were observed in the 200 g/pot of Eucalyptus camaldulensis treated pots with $56.8 \%$ and $76 \%$ for haricot bean and maize respectively. Schumann et al. [19] also reported that water extracts of E. grandis significantly reduced weed establishment. Swaminathan et al. [20] evaluated the allelopathic effect of eight multipurpose trees including Eucalyptus tereticornis on maize, red gram and sesame. All the trees inhibited germination and growth of all the crops. Khan et al. [15] also reported that Eucalyptus camaldulensis extracts reduced maize seedling height and fresh root weight. Sindhu and Hans [21] also reported that all wheat plants grown in pots containing Eucalyptus tereticornis leaf litter grew significantly less well than control plants. Bhaskar et al. [22] observed reduced results of seedling height and number of leaves of finger millet (Eleusine coracana) due to powdered leaf litter of Eucalyptus tereticornis.

The utmost reduction in the mean root length of haricot bean was observed in the 200 g/pot of Eucalyptus grandis treated pots with value of $77.9 \%$, while for maize it was observed in the $150 \mathrm{~g} /$ pot with value of $77.6 \%$. At the same time the highest reduction in the men root length of haricot bean and maize with $76.7 \%$ and $76.4 \%$ respectively were observed in the $200 \mathrm{~g}$ /pot of Eucalyptus camaldulensis treated pots. Al-Juboory and Ahmad [23] also reported that 2.5 and $5 \mathrm{~kg}$ leaf residues of Eucalyptus camaldulensis reduced weed growth especially Sorghum halepenses, cyperus rotundus and convolvulus arvensis. Mizutani [5] reported research results on the allelopathic effects of various plant extracts, which found that Eucalyptus citrodora and Eucalyptus camaldulensis inhibited growth of green foxtail, bamyard grass and rice. Srinivasan et al. [24] also observed the reduced crop germination and growth of vigna mungo, vigna radiata, pigeonpea and soybean, when grown in the top soil taken from Eucalyptus tereticornis. Padhy et al. [25] tested the leaches of senescing and freshly fallen leaves of Eucalyptus globules for their allelopathic effect on an improved cultivar of finger millet in laboratory. Germination, seedling shoots, and root growth were inhibited with the effects increasing with leachates concentration.

The maximum decreases in the mean collar diameter were observed in the $200 \mathrm{~g} / \mathrm{pot}$ of Eucalyptus grandis treated pots with $85.2 \%$ and $76.9 \%$ for haricot bean and maize, and similarly in the 200 g/pot of Eucalyptus camaldulensis treated pots with values of $57.1 \%$ and $66.7 \%$ for haricot bean and maize respectively. These findings are confirmed by the work of Ahmed et al. [12] who reported that leaf litters of L. leucocephala induced inhibitory effects on germination, growth and collar diameter of Falen (Vignaunguiculata), Chickpea (Cicerarietinum) and Arhor (Cajanuscajan). Anwar [26] observed greater allelopathic effects of the fresh leaves extracts of Eucaluptus alba, E. deglupta and E. robusta on the growth of maize seedlings.

According to the mean result a $200 \mathrm{~g} /$ pot treatments of both Eucalyptus species reduced the highest in shoot, root fresh and shoot, root dry weight on haricot bean and maize crops as compared to other treatments. Findings by Lisanework and Michelson [13] also reported that Eucalyptus globules, Eucalyptus camaldulensis and Eucalyptus saligna extract, reduce the fresh weight of maize seedlings. The results from Khan et al. [15] also showed that aqueous extract of Eucalyptus camaldulensis reduced seedlings dry weight, fresh shoot weight and fresh root weight of maize. Sunil and Khara [21] also reported that water extract of leaves (green, brown and decayed) from 6 years old Eucalyptus tereticornis trees and bark were tested for their inhibitory effects on seed germination and primary root and shoot development of phaseolus vulgaris seedling.

\section{Conclusions}

The allelopathic compatibility of multipurpose tree species with companion agricultural crops may be crucial to determine the success of an agroforestry practice or system. Eucalyptus is claimed that it is notorious for having allelopathic effect on growth of agricultural crops growing in its vicinity. The allelopathic effect of E. camaldulensis and E. grandis is investigated on the soil reaction, seed germination, and seedling growth of maize and haricot bean growing in the nursery. It can be concluded from the results that allelochemicals present in the leaf powder of each Eucalyptus suppressed all the parameters measured in the crop species studied, and it is an increased inhibition with the increase of leaf powder application. Among the two tree species, Eucalyptus grandis has more inhibitory effect on both crops as compared to Eucalyptus camaldulensis, and the negative effect of allelochemicals is more pronounced on haricot bean than maize in both tree species. 
It is recommended that maize and haricot bean should not be planted very close to or in association with Eucalyptus trees due to the likely adverse effects (allelopathy) on seed germination and other growth parameters. Thus, there is a need to provide information to farmers about where to plant or not when using the Eucalyptus species and their allelopathic effects on agricultural crops. Further studies are suggested to clarify the possible physiological mechanism related to allelopathic effects of the plants.

\section{Acknowledgements}

Rural Capacity Building Project (RCBP) and Ethiopian Ministry of Agriculture are acknowledged for financing this research project. I thank Dr. Abdu Abdulkadir and Dr. Tesfaye Abebe for their constructive suggestions and comments on this manuscript.

\section{References}

[1] Evans, J. (1992) Plantation Forestry in the Tropics. 2nd Edition, Oxford University Press, New York.

[2] Davidson, J. (1995) Eucalypts Tree Improvement and Breeding. Ministry of Natural Resources Development and Environmental Protection, Addis Ababa.

[3] CNST (Council of the National State of Tigray) (1997) The National State of Tigray Rural Land Proclamation No. 23/ 1997. Council of the National State of Tigray, Mekele.

[4] Jagger, P. and Pender, J. (2000) The Role of Trees for Sustainable Management of Less Favored lands: The Case of Eucalypts in Ethiopia. International Food Research Institute, Washington DC.

[5] Mizutani, J. (1989) Plant Allelochemicals and Their Rates. Forestry Abst. 1993. 7-G. Seed Abst.

[6] El-Khawas, A.S. and Shehata, M.M. (2005) The Allelopathic Potentialities of Acacia nilotica and Eucalyptus rostrata on Monocot (Zea mays L.) and Dicot (Phaseolus vulgaris L.) Plants. Biotechnology, 4, 23-34. http://dx.doi.org/10.3923/biotech.2005.23.34

[7] Bewley, J.D. and Black, M. (1994) Seeds: Physiology of Development and Germination. Plenum Press, New York, 445 p. http://dx.doi.org/10.1007/978-1-4899-1002-8

[8] El-Darier, S.M. (2002) Allelopathic Effects of Eucalyptus rostrata on Growth, Nutrient Uptake and Metabolite Accumulation of Vicia faba L. and Zea mays L. Pakistan Journal of Biological Sciences, 5, 6-11.

[9] Khan, R.A. (2003) Studies on Weed Control in Sugarcane and Allelopathic Effects of Eucalyptus on Field Crops. Ph.D. Thesis, Gomal University, Dera Ismail Khan

[10] Saxena, A., Singh, D.V. and Joshi, N.L. (1996) Autotoxic Effects of Pearl Millet Aqueous Extracts on Seed Germination and Seedling Growth. Journal of Arid Environments, 33, 255-260. http://dx.doi.org/10.1006/jare.1996.0061

[11] Mkula, N.P. (2006) Allelopathic Interference of Silverleaf Nightshade (Solanum elaeagnifolium Cav.) with the Early Growth of Cotton (Gossypium hirsutum L.). University of Pretoria, Pretoria.

[12] Ahmed, R., Hoque, A.T.M.R. and Hossain, M.K. (2008) Allelopathic Effects of Leaf Litters of Eucalyptus camaldulensis on Some Forest and Agricultural Crops. Journal of Forestry Research, 19, 19-24. http://dx.doi.org/10.1007/s11676-008-0003-X

[13] Lisanework, N. and Michelsen, A. (1993) Allelopathy in Agroforestry Systems the Effects of Leaf Extracts of Cupressus lusitanica and Three Eucalyptus spp. on Four Ethiopian Crops. Agroforestry Systems, 21, 63-74. http://dx.doi.org/10.1007/BF00704926

[14] Ebrahim, E.E., Mohammad, H.A. and Mustafa, A.F. (1999) Allelopathy Effect of Eucalyptus and Conocarpus Plantation on Germination and Growth of Two Sorghum Species. Sudan Journal of Agricultural Research, 2, 9-14.

[15] Khan, M.A., Hussain, I. and Khan, E.A. (2007) Effect of Aqueous Extract of Eucalyptus camaldulensis L. on Germination and Growth of Maize. Pakistan Journal of Weed Science Research, 13, 177-182.

[16] Thakur, V.C. and Bhardwaj, S.D. (1992) Allelopathic Effect of Tree Leaf Extracts on Germination of Wheat and Maize. Seed Research, 20, 153-154.

[17] Rao, N.S. and Reddy, P.C. (1984) Studies on the Inhibitory Effects of Eucalyptus (Hybrid) Leaf Extracts on the Germination of Certain Food Crops. Indian Forester, 110, 218-222.

[18] Shivanna, L.R., Prasanna, K.T. and Mumtaz, J. (1992) Allelopathic Effect of Eucalyptus, an Assessment on the Response of Agricultural Crops. Proceedings of the 1st National Symposium. Allelopathy in Agroecosystem, Hisar, India, 12-14 February 1992.

[19] Schumann, A.W., Little, K.M. and Eccles, N.S. (1995) Suppression of Seed Germination and Early Seedling Growth by Plantation Harvest Residues. South African Journal of Plant and Soil, 12, 170-172. 
http://dx.doi.org/10.1080/02571862.1995.10634359

[20] Swaminathan, C., Sivagananam, K. and Srimathi, P. (1993) Allelopathic Proclivities of Multipurpose Trees. My Forest, 29, 147-149.

[21] Sunil, P. and Khara, A. (1991) Allelopathic Effect of Eucalyptus terelicornis on Phaseolus vulgaris Seedling. International Tree Crops Journal, 6, 287-293. http://dx.doi.org/10.1080/01435698.1991.9752893

[22] Bhaskar, V., Arali, A. and Shankara, B.C. (1992) Alleviation of Allelopathic Effects of Eucalyptus Hybrid through Litter Burning. Proceedings of the 1st National Symposium. Allelopathy in Agroecosystem, Hisar, India, 12-14 February 1992.

[23] Al-Juboory, B.A. and Ahmed, M.M. (1994) The Allelopathic Effects of Some Plant Residues on Some Weed Plants. Arab Journal of Plant Protection, 12, 3-10.

[24] Srinivasan, K., Ramswamy, M. and Shantha, R. (1990) Tolerance of Pulse Crops to Allelochemicals of Tree Species. Indian Journal of Pulses Research, 3, 40-44.

[25] Padhy, B., Khan, P.A., Achariya, B. and Bupripata, N.P. (1992) Allelopathic Effects of Eucalyptus Leaves on Seed Germination and Seedling Growth of Finger Millet. In: Tauro, P. and Narwal, S.S., Eds., Proceedings of the First National Symposium. Allelopathy in Agroecosystem, Scientific Publishers, Jodhpur, 102-104.

[26] Anwar, C. (1991) Study of the Allelopathic Effect of Eucalyptus spp. On Growth of Maize Seedlings. Bulletin Penelitian Hutan, 547, 9-17. 